\title{
Pengembangan Butiran Premiks untuk Fortifikasi Zat Besi dalam Beras
}

\section{(The Development of Premix Kernel for Iron Fortification of Rice)}

\author{
Feri Kusnandar*, Faleh Setia Budi, Yustikawati, Yane Regiyana, Slamet Budijanto
}

(Diterima April 2020/Disetujui Juli 2020)

\begin{abstract}
ABSTRAK
Pengembangan beras yang difortifikasi zat besi merupakan upaya untuk meningkatkan asupan zat besi dalam mengatasi masalah anemia di Indonesia. Salah satu bahan pembawa (vehicle) fortifikan zat besi yang dapat dikembangkan adalah butiran premiks (premix kernel) yang ditambahkan ke dalam beras. Butiran premiks diproses dengan mencampurkan tepung beras dengan zat besi hingga homogen, kemudian dicetak dengan ekstruder sehingga menghasilkan butiran menyerupai beras. Penelitian ini bertujuan untuk mengembangkan teknologi pembuatan butiran premiks zat besi dengan ekstruder ulir ganda dan mengevaluasi homogenitas, stabilitas akibat pencucian, dan mutu sensoris beras yang difortikasi. Premiks kernel dibuat dengan mencampurkan tepung beras $(1000 \mathrm{~g})$, feri pirofosfat (yang mengandung $5000 \mathrm{mg}$ Fe), dan GMS (10g) selama 5, 10, 15, 20, 25, dan 30 menit, kemudian ditambahkan air $(450 \mathrm{~mL})$ dan diproses dengan ekstruder pada suhu $80^{\circ} \mathrm{C}$. Proses pencampuran selama 20 menit menghasilkan premiks kernel dengan kadar besi yang relatif seragam $(6030 \pm 135 \mathrm{mg} / \mathrm{kg})$ dengan $2,25 \%$ RSD. Proses pencampuran butiran premiks dan beras Pandanwangi (1:100) selama 25 menit dengan menggunakan blade mixer menghasilkan beras fortifikan dengan kadar zat besi sebesar $39 \mathrm{mg} / \mathrm{kg}$ dengan $13,56 \%$ RSD. Proses pencucian beras fortifikan menurunkan kadar zat besi dan persentase kehilangannya dipengaruhi oleh frekuensi pencucian. Beras dan nasi yang difortifikasi dan tanpa fortifikasi secara keseluruhan tidak berbeda secara organoleptik.
\end{abstract}

Kata kunci: anemia, beras fortifikasi, feri pirofosfat, homogenitas, butiran premiks

\section{ABSTRACT}

Iron-fortified rice potentially increases iron consumption in order to overcome anemia in Indonesia. Premix kernel can be applied as a fortificant vehicle being formulated into rice. The premix kernel is processed by mixing rice flour and iron source and extruded to yield rice-like extrudate. This research aimed to develop iron premix kernel using a double screw extruder and evaluate the fortificant homogeneity during mixing and stability due to washing as well as overall sensory acceptability of fortified rice. The premix kernel was made by mixing rice flour (1000 g), pyrophosphate ferries (containing 5,000 mg Fe), and GMS (10 g) for 5, 10, 15, 20, 25, and 30 minutes, added with water $(450 \mathrm{~mL})$ and passed into an extruder at $80^{\circ} \mathrm{C}$. The dry-mixed for 20 minutes yielded a homogenous premix kernel $(6,030 \pm 135 \mathrm{mg} / \mathrm{kg}$ with RSD of $2.25 \%)$. The mixing of premix kernel and Pandanwangi rice (1:100) for 25 minutes using a blade mixer yielded fortified rice with iron content of $39 \mathrm{mg} / \mathrm{kg}$ and RSD of $13.56 \%$. The washing process of fortified rice decreased iron content, and the percentage of iron loss was affected by the washing frequency. Raw and cooked fortified rice did not differ organoleptically from those without fortification.

Keywords: anemia, fortified rice, ferric pyrophospate, homogeneity, premix kernel

\section{PENDAHULUAN}

Anemia masih menjadi salah satu masalah gizi di Indonesia. Hal ini ditunjukkan oleh jumlah penderita prevalensi anemia yang mencapai $21,7 \%$ penduduk Indonesia yang di antaranya adalah anak-anak prasekolah $(32 \%)$ dan wanita hamil $(30 \%)$ (Kemenkes 2013). Penderita anemia dapat mengalami penurunan daya konsentrasi dan kecerdasan kognitif, penghambatan pertumbuhan, hingga kematian (Allen et al. 2006). Salah satu penyebab kerjadian anemia adalah kekurangan zat besi $(\mathrm{Fe})$ karena zat gizi mikro ini

Departemen IImu dan Teknologi Pangan, Fakultas Teknologi Pertanian, Institut Pertanian Bogor, Kampus IPB Darmaga Bogor 16680

* Penulis Korespondensi:

Email: fkusnandar@apps.ipb.ac.id diperlukan dalam pembentukan proses sintesis hemoglobin (Fairweather et al. 2001). Angka kecukupan gizi (AKG) untuk zat besi berbeda-beda, yaitu untuk bayi/anak 0-9 tahun $(0,3-10 \mathrm{mg})$, laki-laki usia $>10$ tahun $(8-11 \mathrm{mg} / \mathrm{hari})$, perempuan usia $>10$ tahun (8-18 $\mathrm{mg} / \mathrm{hari})$, dan ibu hamil yang bergantung usia kehamilan (8-27 mg/hari) (Kemenkes 2019).

Fortifikasi zat besi pada bahan pangan merupakan upaya untuk meningkatkan asupan zat besi yang diharapkan dapat mengatasi masalah defisiensi zat besi. Fortifikasi adalah penambahan fortifikan secara sengaja ke dalam bahan pangan yang dipilih sebagai pembawa (vehicle) yang bertujuan untuk mengatasi masalah kekurangan mikronutrien tertentu pada suatu populasi (Allen et al. 2006). Tujuan utama fortifikasi adalah untuk meningkatkan status gizi masyarakat dengan cara menambahkan zat gizi yang diperlukan ke dalam bahan pangan vehicle. Salah satu sumber zat 
besi yang direkomendasikan oleh WHO sebagai fortifikan adalah feri pirofosfat (WHO 2018). Feri pirofosfat bersifat tidak larut dalam air, namun sedikit larut asam, memiliki bioavailabilitas yang relatif tinggi (21-74\%), tidak beracun, tidak menyebabkan perubahan sensoris, stabil selama penyimpanan, dan mudah diperoleh. Sumber zat besi lainnya yang direkomendasikan di antaranya adalah ferosulfat, fero fumarat, dan fero bisglisinat (Allen et al. 2006; Valcárcel et al. 2019). Produk yang difortifikasi zat besi telah dilaporkan, seperti pada tepung-tepungan (Richins et al. 2008), kecap (Naruki et al. 2009), nasi pratanak (Prom-u-thai et al. 2009), biskuit (Biebinger et al. 2009; Mohammadi et al. 2011; Setyawati et al. 2018), bumbu mi instan (Priambudi et al. 2017), makanan ringan (Chairil \& Kustiyah 2014; Penugonda et al. 2018), dan infant cereal (Lisa et al. 2017).

Beras giling mengandung zat besi yang berbedabeda bergantung pada varietasnya, yaitu berkisar $3,15-4,2 \mathrm{mg} / \mathrm{kg}$. Dalam bentuk nasi, kandungan zat besi sedikit menurun menjadi $3,10-4,0 \mathrm{mg} / \mathrm{kg}$ (Indrasari et al. 2002). Dengan demikian, dengan asumsi konsumsi beras sebesar 0,306 kg/kapita/hari (BPS 2017) maka beras berkontribusi sebesar 9,5-12,24\% AKG (untuk anak-anak usia 9 tahun dengan AKG $10 \mathrm{mg}$ Fe/hari) dan 3,5-4,5\% AKG (untuk ibu hamil trimester 3 dengan AKG $27 \mathrm{mg} \mathrm{Fe} /$ hari).

Beras sebagai sumber karbohidrat utama dapat ditingkatkan kadar zat besinya dengan cara difortifikasi (Hotz et al. 2008; Beinner et al. 2010). Fortifikasi beras direkomendasikan juga oleh WHO (2018) karena beras dikonsumsi secara luas dan teratur oleh masyarakat. Beras fortifikasi dapat diproduksi secara masal dengan teknologi yang relatif sederhana. Penelitian mengenai beras yang difortifikasi dengan zat besi dilaporkan oleh Losso et al. (2017) dan Hackl et al. (2019). Permasalahan yang dihadapi oleh beras yang difortifikasi adalah praktik di rumah tangga yang biasanya melakukan pencucian beras sebelum dimasak. Di samping itu, pencucian beras dapat menyebabkan kehilangan zat fortifikan (Indrasari 2006). Kehilangan zat fortifikan ini dipengaruhi oleh lama pencucian, volume air yang digunakan, dan proses pengadukan (Furter et al. 1946).

Alternatif teknologi fortifikasi zat besi yang dapat dikembangkan adalah dengan membuat butiran premiks yang terbuat dari campuran tepung beras dan feri pirofosfat. Butiran premiks merupakan campuran zat gizi mikro dengan bahan lain yang ditambahkan dan dibentuk menyerupai beras (Allen et al. 2006). Fortifikan dalam bentuk butiran premiks ini diharapkan dapat meminimalkan kehilangan zat besi pada saat dicampurkan ke dalam beras dan selama pemasakan beras menjadi nasi. Belum ada penelitian yang melaporkan pengembangan fortifikan zat besi dalam bentuk butiran premiks yang ditambahkan ke dalam beras.

Butiran premiks ini berbentuk butiran beras yang dapat dihasilkan dengan menggunakan teknologi ekstrusi panas (hot extrusion). Prinsip teknologi ekstrusi adalah melewatkan bahan premiks basah melalui ekstruder pada suhu di atas $70^{\circ} \mathrm{C}$ (Mishra et al. 2012). Penggunaan teknologi ekstrusi dalam fortifikasi beras dilaporkan oleh Kuong et al. 2016), namun bukan dalam bentuk butiran premiks. Teknologi ekstrusi dapat menghasilkan butiran premiks yang menyerupai beras dan menghasilkan produk dengan karakterisitik sensoris yang baik (Hussain et al. 2014). Dalam premiks dapat ditambahkan emulsifier gliserol monostearat (GMS) yang berfungsi untuk mengikat bahan dan membantu pembentukan butiran premiks selama proses ekstrusi (Budi et al. 2013). GMS juga membantu agar butiran premiks yang dihasilkan tidak lengket. Penggunaan GMS sudah digunakan dalam produk beras analog yang diproses dengan teknologi ekstrusi (Budijanto \& Yuliyanti 2012; Noviasari et al. 2013; Noviasari et al. 2015). Dalam bentuk butiran premiks, beras fortifikan diharapkan secara visual tidak dapat dibedakan dari beras tanpa fortifikasi. Fortifikan zat besi dalam bentuk butiran premiks juga diharapkan lebih stabil dan kompak sehingga tidak banyak hilang selama pencucian dan pengolahan beras fortifikasi.

Penelitian ini bertujuan untuk mengembangkan teknologi pembuatan butiran premiks sebagai vehicle fortifikan zat besi, khususnya menentukan lama waktu proses pencampuran tepung beras, feri pirofosfat, dan GMS yang optimum yang dapat menghasilkan butiran premiks yang homogen, beras fortifikasi yang stabil selama proses pencucian, dan dapat diterima secara organoleptik.

\section{METODE PENELITIAN}

\section{Bahan dan Alat}

Bahan yang digunakan untuk pembuatan butiran premiks adalah tepung beras komersial, fortifikan feri pirofosfat $\left(\mathrm{Fe}_{4}\left(\mathrm{P}_{2} \mathrm{O}_{7}\right)_{3}\right)$ (bobot molekul: $745,21 \mathrm{~g} / \mathrm{mol}$ ) yang diperoleh dari DSM Singapore, dan gliserol monostearat (GSM) yang diperoleh dari suplier PT. Lautan Luas, Jakarta. Beras yang digunakan adalah beras Pandanwangi yang diperoleh dari pasar lokal di Bogor. Semua bahan kimia yang digunakan untuk analisis kimia adalah analytical grade.

Peralatan yang digunakan dalam pembuatan butiran premiks adalah ekstruder ulir ganda (Berto BEX-DS 2256, Indonesia), dry blender (Panasonic MXGM1011, Jepang), blade mixer (Sigma, Indonesia), timbangan analitik (Kern ABS 220-4, AS), dan oven pengering (Binder, Jerman). Peralatan utama yang digunakan untuk analisis adalah atomic absorption spectroscopy (AAS) (Hitachi type Zeeman 200, Jepang).

\section{Pembuatan Butiran Premiks}

Tepung beras $(1000 \mathrm{~g})$, feri pirofosfat $(16634,15 \mathrm{mg}$ atau setara dengan kadar Fe sebesar $5000 \mathrm{mg}$ ), dan GMS (10 g) dicampurkan dengan menggunakan dry blender selama 5, 10, 15, 20, 25, dan 30 menit. Sampel campuran kemudian dianalisis dengan metode AAS 
untuk menentukan tingkat homogenitas (pada setiap waktu pengambilan sampel dipilih lima titik yang berbeda). Waktu pencampuran yang dipilih dalam proses pembuatan butiran premiks ditetapkan berdasarkan perlakuan yang mempunyai persen relative standard deviation (\%RSD) paling rendah. Pengujian dilakukan dua ulangan dan analisis dilakukan duplo pada setiap titik pengambilan sampel.

Bahan premiks selanjutnya ditambah air $(450 \mathrm{~mL}$ atau $45 \%$ dari tepung beras), diaduk secara merata, dan diproses dengan mesin ekstruder ulir ganda untuk menghasilkan butiran premiks. Suhu barrel ekstruder ditentukan pada suhu $80^{\circ} \mathrm{C}$. Selama proses ekstrusi, bahan mengalami proses shearing, pencetakan, dan pembentukan butiran premiks yang menyerupai butiran beras setelah melewati die. Butiran premiks yang dihasilkan kemudian dikeringkan dalam oven pengering pada suhu $50^{\circ} \mathrm{C}$ selama 2 jam. Butiran premiks yang dihasilkan selanjutnya dianalisis kadar besinya (metode AAS). Percobaan dilakukan dua kali ulangan dan analisis untuk masing-masing ulangan dilakukan triplo. Kadar besi dinyatakan dalam basis kering. Kadar air untuk menghitung sampel kering dianalisis dengan metode gravimetri (AOAC 2005).

\section{Pembuatan Beras Fortifikan}

Beras fortifikasi dibuat dengan mencampurkan satu bagian butiran premiks dengan 100 bagian beras dengan blade mixer (Allen et al. 2006). Hasil pencampuran ini memberikan kadar besi sekitar 50 $\mathrm{mg} / 1000 \mathrm{~g}$ beras (basis basah). Penetapan waktu proses pencampuran dilakukan dengan cara pengambilan contoh pada menit ke-5, 10, 15, 20, dan 25 (masing-masing diambil lima titik pengambilan yang berbeda). Sampel dianalisis dengan metode AAS dan waktu pencampuran yang dipilih didasarkan pada $\%$ RSD yang paling rendah.

\section{Uji Stabilitas Beras Fortifikasi Selama Pencucian}

Beras yang difortifikasi dicuci dengan perbandingan satu cup beras (setara dengan $150 \mathrm{~g}$ ) dengan menggunakan tiga cup air. Perlakuan pencucian beras fortifikasi dilakukan sebanyak satu kali, dua kali, dan tiga kali. Beras fortifikasi tanpa pencucian juga diambil contohnya untuk digunakan sebagai kontrol. Sampel beras fortifikasi dianalisis kadar besinya dengan metode AAS (konsentrasi zat besi dinyatakan dalam basis kering). Kadar air untuk menghitung bobot kering sampel dianalisis dengan metode gravimetri (AOAC 2005).

\section{Analisis Kadar Besi (AOAC 2005)}

Larutan sampel untuk analisis kadar besi disiapkan dengan metode pengabuan basah. Sebanyak 1,0-1,2 $\mathrm{g}$ sampel ditimbang dalam labu Kjehdahl, lalu ditambahkan $10 \mathrm{~mL} \mathrm{HNO}_{3}$ dan $3 \mathrm{~mL} \mathrm{HClO}_{4}$. Sampel kemudian dipanaskan selama 1,5 jam hingga terbentuk larutan bening. Setelah didinginkan, sebanyak $10 \mathrm{~mL}$ air demineral ditambahkan, lalu dipanaskan kembali selama 10 menit. Setelah didinginkan, 30-50
$\mathrm{mL}$ air demineral ditambahkan kembali. Contoh larutan pada labu disaring menggunakan kertas saring ke dalam labu takar $100 \mathrm{~mL}$. Larutan sampel dianalisis dengan menggunakan AAS. Kurva standar dari larutan besi standar $(0 ; 0,5 ; 1 ; 2 ; 4$; 8; dan $16 \mathrm{mg} / \mathrm{L})$ juga disiapkan dan kadar besi dinyatakan dalam satuan $\mathrm{mg} / \mathrm{L}$.

\section{Uji Organoleptik (BS 2004)}

Uji segitiga dilakukan untuk mengevaluasi perbedaan penerimaan sensori antara beras dan nasi yang difortifikasi. Pengujian dilakukan untuk mengevaluasi apakah panelis dapat membedakan beras dan nasi yang difortifikasi dengan beras dan nasi yang tidak difortifikasi. Uji sensoris dilakukan oleh 30 orang panelis terlatih untuk menilai penerimaan secara keseluruhan (overall difference test). Uji dilakukan dengan menyajikan tiga contoh yang terdiri atas dua contoh yang sama dan satu contoh yang berbeda dari sampel beras dan nasi. Sampel beras dibandingkan untuk atribut keseluruhan berdasarkan penerimaan atas warna dan aroma. Sampel nasi disiapkan dengan cara menanak nasi dengan rice cooker (beras : air=1: 1), lalu sampel nasi disajikan kepada panelis setelah dingin. Penerimaan keseluruhan berdasarkan penerimaan warna, aroma, dan rasa nasi. Data hasil uji sensoris dianalisis dengan menggunakan tabel peluang binomial (BS 2004), yaitu penilaian benar (panelis dapat membedakan antarsampel) atau penilaian salah (panelis tidak dapat membedakan antarsampel). Sampel beras atau nasi fortifikasi dinyatakan tidak dapat dibedakan dari beras atau nasi tanpa fortifikasi apabila penilaian salah lebih dari $50 \%$ (untuk $n=30$ orang).

\section{Analisis Data}

Penentuan tingkat homogen waktu pencampuran dilakukan dengan menghitung \%RSD. Data hasil pengaruh pencucian pada kadar zat besi pada beras fortifikasi dianalisis ragam satu faktor dengan SPSS Statistic 20.0. Perlakuan yang signifikan dianalisis dengan uji lanjut Dunnet pada taraf kepercayaan $5 \%$.

\section{HASIL DAN PEMBAHASAN}

\section{Homogenitas butiran premiks}

Butiran premiks harus dibuat dari bahan premiks yang homogen. Homogenitas zat besi dalam campuran sangat penting karena zat besi yang ditambahkan relatif kecil. Homogenitas zat besi dalam campuran bahan dipengaruhi oleh lama waktu pencampuran (Harnby et al. 2001). Bahan kering mencapai homogen apabila hasil analisis kadar zat besi pada bahan premiks bersesuaian dengan kadar zat besi yang ditambahkan yang ditunjukkan dengan \%RSD-nya. Fortifikan yang ditambahkan adalah dalam bentuk feri pirofosfat yang mengandung $5000 \mathrm{mg}$ zat besi yang setara dengan $30,1 \%$ dari bobot feri pirofosfat yang ditambahkan. Proses pencampuran dianggap 
homogen apabila \%RSD relatif kecil. Semakin kecil \%RSD maka semakin kecil ragam dan semakin tinggi ketelitian (Feldsine 2002). Tabel 1 menunjukkan kadar zat besi dan \%RSD-nya pada setiap periode pengambilan sampel selama proses pencampuran (setiap 5 menit selama 30 menit). Kadar zat besi pada campuran tepung dengan berbagai waktu pencampuran mencapai homogen pada proses pencampuran kering selama 20, 25, dan 30 menit, yaitu pada saat \%RSD kecil dan relatif tidak berubah $(3,37-3,87 \%)$. Menurut Lisa et al. (2017), pencampuran dinilai homogen apabila memberikan $\% R S D<2,0 \%$. Proses pencampuran bahan premiks yang dipilih adalah 20 menit $(3,81 \%$ RSD). Pemilihan waktu 20 menit didasarkan pada waktu yang terpendek karena sudah memadai untuk menghasilkan premiks yang homogen, walaupun belum mencapai \%RSD yang ideal.

Bahan premiks kemudian ditambah air dan dimasukkan ke dalam mesin ekstruder untuk diproses menjadi butiran premiks. Sampel butiran premiks kemudian dikonfirmasi lagi tingkat homogenitasnya dengan menganalisis kembali kadar besi yang hasilnya disajikan pada Tabel 2. Dari dua kali ulangan proses dan masing-masing ulangan dilakukan pengambilan sampel pada lima titik, rata-rata kadar besi pada butiran premiks adalah $6030,38 \pm 135,38 \mathrm{mg} / \mathrm{kg}$ (bk) dengan rata-rata $2,25 \%$ RSD. Hal ini menunjukkan bahwa butiran premiks yang dihasilkan dari proses pencampuran bahan dan ekstrusi memberikan kadar besi yang relatif seragam. Nilai \%RSD yang dihasilkan dalam penelitian ini masih lebih tinggi dari yang dilaporkan oleh Lisa et al. (2017), yaitu $<2 \%$ pada infant cereal yang difortifikasi dengan zat besi. Penelitian Lisa et al. (2017) menggunakan double paddle mixer yang dapat mencampur bahan lebih homogen.

\section{Homogenitas Beras Fortifikasi}

Beras fortifikasi harus mengandung zat besi yang relatif seragam sehingga proses pencampuran butiran premiks dan beras harus mencukupi. Tabel 3

Tabel 1 Kadar zat besi pada berbagai waktu pencampuran bahan tepung beras, feri pirofostat, dan gliserol monostearat

\begin{tabular}{ccl}
\hline Menit ke- & Kadar zat besi $(\mathrm{mg} / \mathrm{kg})$ & RSD $(\%)$ \\
\hline 5 & $5020,23 \pm 616,18$ & 12,27 \\
10 & $5017,81 \pm 442,62$ & 8,82 \\
15 & $4985,12 \pm 246,65$ & 4,95 \\
20 & $4834,99 \pm 184,08$ & 3,81 \\
25 & $4865,15 \pm 188,43$ & 3,87 \\
30 & $4833,82 \pm 162,74$ & 3,37 \\
\hline
\end{tabular}

Tabel 2 Kadar air dan kadar besi butiran premiks

\begin{tabular}{lrrr}
\hline Ulangan & $\begin{array}{c}\text { Kadar } \\
\text { air (\%) }\end{array}$ & $\begin{array}{r}\text { Kadar besi }(\mathrm{mg} / \mathrm{kg}, \\
\text { bk) }\end{array}$ & $\begin{array}{c}\text { RSD } \\
(\%)\end{array}$ \\
\hline 1 & 11,24 & $6126,07 \pm 90,14$ & 1,66 \\
2 & 8,57 & $5934,61 \pm 121,75$ & 2,24 \\
\hline $\begin{array}{l}\text { Rata-rata } \\
\text { Rata-rata }\end{array}$ & & $6030,38 \pm 135,38$ & \\
$\%$ RSD & & & 2,25 \\
\hline
\end{tabular}

menunjukkan kadar zat besi dan \%RSD pada setiap 5 menit waktu pencampuran selama 30 menit. Hasilnya menunjukkan variasi yang cukup besar yang ditunjukkan dari nilai rata-rata kadar zat besinya $(25,62 \pm$ $15,65-45,59+16,88 \mathrm{mg} / \mathrm{kg})$ dan \%RSD-nya $(13,56-$ $61,12 \%)$. Berdasarkan \%RSD, waktu pencampuran yang memberikan kadar besi yang relatif seragam adalah 25 menit, yaitu $38,57 \pm 5,23 \mathrm{mg} / \mathrm{kg}(\mathrm{bb})$ dengan \%RSD 13,56\%. Nilai \%RSD pada menit ke-25 masih jauh dari kondisi \%RSD yang ideal, namun paling kecil dibandingkan dengan data pada waktu pencampuran lainnya. Nilai \%RSD yang relatif masih tinggi menunjukkan proses pencampuran butiran premiks dan beras masih belum seragam. Hal ini dapat disebabkan mesin pencampur yang digunakan dalam penelitian ini adalah blade mixer yang mencampur bahan stasioner dua arah yang diduga kurang efisien dalam mencampur beras dan butiran premiks yang jumlahnya relatif kecil.

\section{Stabilitas Beras Fortifikasi selama Pencucian}

Proses pencucian beras biasanya dilakukan sebelum memasak nasi sehingga perlu dievaluasi tingkat penurunan kadar zat besi akibat pencucian. Tabel 4 menyajikan kadar besi beras fortifikasi setelah pencucian 1-3 kali. Beras fortifikasi yang mengalami proses pencucian mengandung zat besi yang lebih rendah dibandingkan dengan beras fortifikasi tanpa pencucian. Frekuensi pencucian selama satu hingga tiga kali secara signifikan menyebabkan penurunan kadar besi (berkisar 8,63-20,52\%). Penurunan kadar besi akibat pencucian disebabkan oleh terkikisnya butiran premiks oleh air dan sebagian terbawa ke dalam air cucian. Persentase kehilangan zat besi dari penelitian ini lebih rendah dari yang dilaporkan oleh Steiger et al. (2014), yaitu berkisar 20-60\%. Hal ini dapat disebabkan oleh sifat feri pirofosfat yang tidak larut dalam air sehingga kehilangannya selama pencucian menjadi lebih sedikit. Di samping itu, fortifikan dalam bentuk butiran premiks lebih stabil dan kompak yang tidak mudah larut dalam air.

Beras Pandanwangi dalam bentuk beras giling mengandung zat besi $3,65 \mathrm{mg} / \mathrm{kg}$ (Indrasari et al. 2002). Penambahan butiran premiks fortifikan meningkatkan kadar zat besi yang tinggi pada beras, yaitu 10,56 kali. Dengan perkiraan konsumsi beras per kapita per tahun di Indonesia sebesar $111,58 \mathrm{~kg}$ atau $0,306 \mathrm{~kg} / \mathrm{hari}$ (BPS 2017) maka beras dapat berkontribusi sebesar $11,79 \mathrm{mg}$ zat besi per hari. Proses pencucian yang dapat menghilangkan kadar zat besi sebesar 20,52\% (dengan asumsi frekuensi pencucian tiga kali) maka kontribusi beras fortifikan terhadap AKG

Tabel 3 Kadar besi pada beras fortifikasi selama proses pencampuran

\begin{tabular}{ccc}
\hline Menit ke- & Kadar besi $(\mathrm{mg} / \mathrm{kg}, \mathrm{bb})$ & $\%$ RSD \\
\hline 5 & $38,03 \pm 11,07$ & 29,10 \\
10 & $25,62 \pm 15,65$ & 61,12 \\
15 & $32,22 \pm 10,08$ & 31,29 \\
20 & $45,59 \pm 16,88$ & 37,03 \\
25 & $38,57 \pm 5,23$ & 13,56 \\
\hline
\end{tabular}


Tabel 4 Perubahan kadar besi beras fortifikasi setelah proses pencucian

\begin{tabular}{|c|c|c|c|c|c|c|}
\hline Ulangan & Frekuensi pencucian & $\begin{array}{c}\text { Kadar air } \\
(\%)\end{array}$ & Kadar Fe (mg/kg, bk) & RSD (\%) & $\begin{array}{l}\text { Persentase } \\
\text { kehilangan }\end{array}$ & $\begin{array}{r}\text { Rata-rata } \\
\text { persentase } \\
\text { kehilangan }\end{array}$ \\
\hline $\begin{array}{l}1 \\
2\end{array}$ & Tanpa pencucian & $\begin{array}{l}12,36 \\
12,45\end{array}$ & $\begin{array}{l}78,41 \pm 4,81 \\
83,67 \pm 3,93\end{array}$ & $\begin{array}{l}6,14 \\
4,70\end{array}$ & - & - \\
\hline $\begin{array}{l}1 \\
2\end{array}$ & Satu kali & $\begin{array}{l}7,97 \\
8,09\end{array}$ & $\begin{array}{l}75,54 \pm 1,62 \\
72,28 \pm 3,67\end{array}$ & $\begin{array}{l}2,14 \\
5,07\end{array}$ & $\begin{array}{l}3,66 \\
13,60\end{array}$ & 8,63 \\
\hline $\begin{array}{l}1 \\
2\end{array}$ & Dua kali & $\begin{array}{l}7,49 \\
7,48\end{array}$ & $\begin{array}{l}73,28 \pm 6,16 \\
67,83 \pm 1,41\end{array}$ & $\begin{array}{l}8,41 \\
2,08\end{array}$ & $\begin{array}{l}6,55 \\
18,93\end{array}$ & 12,74 \\
\hline $\begin{array}{l}1 \\
2 \\
\end{array}$ & Tiga kali & $\begin{array}{l}6,22 \\
6,26 \\
\end{array}$ & $\begin{array}{l}64,38 \pm 3,38 \\
64,30 \pm 15,54\end{array}$ & $\begin{array}{l}5,25 \\
24,17 \\
\end{array}$ & $\begin{array}{l}17,89 \\
24,17 \\
\end{array}$ & 20,52 \\
\hline
\end{tabular}

sebesar 9,37 mg per hari atau berkontribusi sebesar 93,7\% (bagi anak-anak usia 9 tahun) dan 34,7\% (untuk wanita hamil trimester 3 dengan AKG $27 \mathrm{mg} /$ hari).

\section{Penerimaan Organoleptik}

Hasil uji segitiga menunjukkan bahwa dari 30 orang panelis yang menilai, yang menjawab benar (dapat membedakan contoh beras fortifikasi dan nonfortifikasi) adalah sebanyak tujuh orang (23,3\%), sedangkan contoh nasi fortifikasi sebanyak delapan orang $(26,7 \%)$ (Tabel 5). Berdasarkan tabel peluang binomial pada taraf kepercayaan 95\% (BS 2004), yaitu panelis yang menjawab benar kurang dari $50 \%$ maka hasil ini menunjukkan bahwa beras yang difortifikasi dan tanpa fortifikasi tidak dapat dibedakan secara organoleptik. Berdasarkan kriteria penilaian keseluruhan yang digunakan maka warna, rasa, dan aroma beras dan nasi yang difortikasi relatif tidak mengalami perubahan.

\section{KESIMPULAN}

Butiran premiks dapat dikembangkan sebagai vehicle untuk fortifikan zat besi. Butiran premiks berbahan dasar tepung beras (basis $1000 \mathrm{~g}$ ) dapat diproses dengan teknologi ekstrusi, yaitu dengan mencampur tepung beras, feri pirofosfat (yang mengandung $5000 \mathrm{mg} \mathrm{Fe}$ ), dan GMS (10 g) selama 20 menit. Hasil campuran bahan ditambah air $(450 \mathrm{~mL})$ dan diproses ekstrusi panas pada suhu $80^{\circ} \mathrm{C}$. Proses ini memberikan butiran premiks dengan kadar besi yang relatif seragam $(6030 \pm 135 \mathrm{mg} / \mathrm{kg}$, bk) dengan $2,25 \%$ RSD. Proses pencampuran butiran premiks dengan beras Pandanwangi selama 25 menit dengan menggunakan blade mixer memberikan beras fortifikan dengan kadar besi sebesar $38,57 \mathrm{mg} / \mathrm{kg}$ (bb) dengan $13,56 \%$ RSD. Proses pencucian beras fortifikasi menurunkan kadar zat besi. Semakin banyak frekuensi pencucian maka persentase kehilangan zat besi semakin besar. Beras dan nasi yang difortifikasi dan tanpa fortifikasi secara keseluruhan tidak dapat dibedakan secara organoleptik.
Tabel 5 Hasil uji segitiga beras dan nasi yang difortifikasi berdasarkan parameter penerimaan keseluruhan $(n=30)$

\begin{tabular}{lcc}
\hline \multicolumn{1}{c}{ Hasil penilaian } & $\begin{array}{c}\text { Beras } \\
\text { difortifikasi }\end{array}$ & Nasi difortifikasi \\
\hline $\begin{array}{l}\text { Panelis menilai } \\
\text { benar }\end{array}$ & $7(23,3 \%)$ & $8(26,7 \%)$ \\
$\begin{array}{l}\text { Panelis menilai } \\
\text { salah }\end{array}$ & $23(76,7 \%)$ & $22(73,3 \%)$ \\
\hline
\end{tabular}

\section{DAFTAR PUSTAKA}

Allen L, de Benoist B, Dary O, Hurrell R. 2006. Guidelines on Food Fortification with Micronutrient. Geneva, Switzerland/Rome, Italy (IT): World Health Organization/Food and Agriculture Organization of United Nations.

[AOAC] Association of Official Analytical Chemistry. 2005. Official Method of Analysis. Association of Official Analytical Chemistry. Rinsington DC.

Biebinger R, Zimmermann MB, Al-Hooti SN, Al-Hamed N, Al-Salem E, Zafar T, Kabir Y, Al-Obaid I, Petry N, Hurrell RF. 2009. Efficacy of wheat-based biscuits fortified with microcapsules containing ferrous sulfate and potassium iodate or a new hydrogenreduced elemental iron: a randomised, doubleblind, controlled trial in Kuwaiti women. British Journal of Nutrition. 102(9): 1362-1369. https:// doi.org/10.1017/S0007114509990353

Beinner MA, Gustavo VM, Milene CP, Ted, G. 2010. Iron-fortified rice is as efficasious as supplemental iron drops in infants and young children. The Journal of Nutrition. 140: 49-53. https://doi.org/ 10.3945/jn.109.112623

[BS] British Standards (UK). 2004. Sensory AnalysisMethodology-Triangle Test. BS 4120:2004.

[BPS] Badan Pusat Statistika. 2017. Kajian Konsumsi Bahan Pokok 2017. Jakarta (ID).

Budi FS, Hariyadi P, Budijanto S, Syah D. 2013. Teknologi proses ekstrusi untuk membuat beras analog. Pangan. 22(3): 263-274. 
Budijanto S, Yuliyanti. 2012. Studi persiapan tepung sorgum (Sorghum bicolor L. Moench) dan aplikasinya pada pembuatan beras analog. Jurnal Teknik Pertanian. 13(3): 177-186.

Chairil MMF, Kustiyah L. 2014. Formulasi flakes berbasis pati garut dengan fortifikasi zat besi (fe) untuk perbaikan status besi remaja putri. Jurnal Gizi Dan Pangan. 9(2): 89-96.

Fairweather-Tait SJ, Wortley GM, Teucher B, Dainty J. 2001. Iron absorption from a breakfast cereal: effects of EDTA compounds and ascorbic acid. International Journal for Vitamin and Nutrition Research. 71(2): 117-22. https://doi.org/10. 1024/0300-9831.71.2.117

Feldsine P, Abeyta, Andrews C, Wallace H. 2002. AOAC international methods committee guidelines for validation of qualitative and quantitative food microbiological official methods of analysis. Journal of AOAC International. 85(5): 1187-1200. https:// doi.org/10.1093/jaoac/85.5.1187

Furter MF, Lauter WM, De Ritter E, Rubin SH. 1946. Enrichment of rice with synthetic vitamin and iron. Industrial and Engineering Chemistry. 38(5): 486493. https://doi.org/10.1021/ie50437a014

Hackl LS, Abizari AR, Speich C, Zungbey-Garti, H, Cercamondi C., Zeder I, Zimmermann MB. Moretti D. 2019. Micronutrient-fortified rice can be a significant source of dietary bioavailable iron in schoolchildren from rural Ghana. Science Advance. 5(3): 1-9. https://doi.org/10.1126/sciadv.aau0790

Harnby M, Edwards MF, Nienow AW. 2001. Mixing in the Process Industries. Elsevier Ltd, Barkeley.

Hotz C, Maribel P, Germán O., Armando GG., Terry E, Shirley J, Ted G. 2008. Efficacy of iron-fortified ultra rice in improving the iron status of women in Mexico. Bulletin Food and Nutrition. 29(2): 140-149. https://doi.org/10.1177/156482650802900208

Hussain SZ, Baljit S, Rather AH. 2014. Efficacy of micronutrient fortified extruded rice in improving the iron and vitamin A status in Indian schoolchildren. International Journal of Agriculture and Food Science Technology. 5(3): 227-238.

Indrasari SD. 2006. Kandungan Mineral Padi Varietas Unggul dan Kaitannya dengan Kesehatan. Iptek Tanaman Pangan. 1(1): 88-99.

Indrasari SD, Hanarida I, Daradjat AA. 2002. Breeding for iron dense rice: a low cost, sustainable approach to reducing anemia in Asia. Indonesian Final Report Year I. International Food Policy Research Institute (IFPRI) and Indonesian Center Food Crops Research and Development (ICFORD) (nutrition aspect).

[Kemenkes RI] Kementerian Kesehatan RI. 2013. Riset Kesehatan Dasar 2013. Jakarta (ID).
[Kemenkes RI] Kementerian Kesehatan RI. 2019. Peraturan Menteri Kesehatan Republik Indonesia Nomor 28 TAHUN 2019 tentang Angka Kecukupan Gizi yang Dianjurkan untuk Masyarakat Indonesia.

Kuong K, Laillou A, Chea C, Chamnan C, Berger J, Wieringa FT. 2016. Stability of vitamin a, iron and zinc in fortified rice during storage and its impact on future national standards and programs-case study in Cambodia. Nutrients. 8: 1-9. https://doi. org/10.3390/nu8010051

Lisa, Kusnandar F, Suyatma NE. 2017. Iron fortification of soya based infant cereal and its stability during storage. Journal of Food Technology and Preservation. 1(2): 16-2.

Losso JN, Karki N, Muyonga J, Wu Y, Fusilier K, Jacob G, Yu Y, Rood JC, Finley JW, Greenway FL. 2017. Iron retention in iron-fortified rice and use of ironfortified rice to treat women with iron deficiency: $A$ pilot study. BBA Clinical. 8: 78-83. https:// doi.org/10.1016/j.bbacli.2017.09.001

Mishra A, Mishra HN, Rao PS. 2012. Preparation of rice analogues using extrusion technology. International Journal of Food Science Technology. 47: 1789-1797. https://doi.org/10.1111/j.13652621.2012.03035.x

Mohammadi M, Abedi AS, Azizi MH, Ahmadian FS, Pouraram H. 2011. Development of fortified biscuit using NaFeEDTA. Journal of the Science of Food and Agriculture.91(11): 1984-19849. https:// doi.org/10.1002/jsfa.4405

Naruki S, Astuti M, Marsono Y, Raharjo S. 2009. Sifat prooksidatif fortifikan NaFeEDTA dan Fe-sulfat pada kecap hasil fortifikasi. Agritech. 29(2): 59-63.

Noviasari S, Kusnandar F, Budijanto S. 2013. Pengembangan beras analog dengan memanfaatkan jagung putih. Jurnal Teknologi dan Industri Pangan. 24: 195-201. https:// doi.org/10.6066/jtip.2013.24.2.194

Noviasari S, Kusnandar F, Setiyono A, Budijanto S. 2015. Beras analog sebagai pangan fungsional dengan indeks glikemik rendah. Jurnal Gizi Pangan. 10(3): 225-232

Penugonda K, Fiorentino NM, Alavi S, Lindshield BL. 2018. Bioavailable iron and vitamin a in newly formulated, extruded corn, soybean, sorghum, and cowpea fortified-blended foods in the in vitro digestion/caco-2 cell model. Current Developments in Nutrition. 2(7): 1-10. https://doi.org/ $10.1093 / \mathrm{cdn} / \mathrm{nzy} 021$

Priambudi AP, Kusnandar F, Palupi NS. 2017. Stabilitas dan bioavalaibilitas in vitro zat besi sebagai fortifikan dalam bumbu mi instan. Jurnal IImu Pangan dan Hasil Pertanian. 1(1): 37-53. https://doi.org/10.26877/jiphp.v111.1364

Prom-u-thai C, Rerkasem B, Fukai S, Huang L. 2009. 
Iron fortification and parboiled rice quality: appearance, cooking quality and sensory attributes. Journal of the Science of Food and Agriculture. 2(4): 323-328. https://doi.org/10.1002/jsfa.3753

Richins AT, Burton KE, Pahulu HF, Jefferies, Dunn M. 2008. Effect of iron source on color and appearance of micronutrient-fortified corn flour tortillas. Cereal Chemistry. 85(4): 561-565. https://doi.org/ 10.1094/CCHEM-85-4-0561

Setyawati R, Dwiyanti H, Aini N. 2018. Pengaruh fortifikasi zat besi terhadap sifat kimia dan sensori biskuit ubi kayu yang disuplementasi tepung ikantempe. Agritech. 38 (4): 396-403. https:// doi.org/10.22146/agritech.39522
Steiger G, Nadina MF, Hector C, Beatrice CP. 2014. Fortification of rice: technologies and nurients. Annals of the New York Academy of Sciences. 1324: 29-39 https://doi.org/10.1111/nyas.12418

Valcárcel AMC, Graciá CM, Miró SM, Sánchez JM, Bermúdez CAG, Asensi GD, Nicolás RL, Pascual MS. 2019. Iron bioavailability of four iron sources used to fortify infant cereals, using anemic weaning pigs as a model. European Journal of Nutrution. 58(5): 1911-1922. https://doi.org/ 10.1007/s00394018-1742-x

[WHO] World Health Organization. 2018. Guideline: Fortification of Rice with Vitamins and Minerals as a Public Health Strategy. Genewa $(\mathrm{CH})$. 